перебування, соціального статусу та професійної підготовки. Теоретичні аспекти альтернативного навчання іноземних мов потребують подальшого дослідження, як i розроблення нових, адекватних меті навчання методів.

\title{
Література
}

1. Gutzat B. Fremdsprachenlernen über Fernstudien / B. Gutzat // Handbuch Fremdsprachenunterricht / [K.-R. Bausch, H. Christ, H.-J. Krumm]. - 5. Auflage. - Tübingen ; Basel : A. Francke, 2007. - S. 195-197. 2. Jung U. O. H. Fremdsprachenlernen gesteuert durch Massenmedien / U. O. H. Jung // Handbuch Fremdsprachenunterricht / [K.-R. Bausch, H. Christ, H.-J. Krumm]. - 5. Auflage. - Tübingen ; Basel : A. Francke, 2007. - S. 192-194. 3. Fachlexikon Deutsch als Fremd- und Zweitsprache/ [H. Barkowski, H.-J. Krumm].Tübingen; Basel : A. Franke Verlag, 2010. - 370 s. 4. Pleines J. Intensivunterricht / J. Pleines / Handbuch Fremdsprachenunterricht / [K.-R. Bausch, H. Christ, H.-J. Krumm]. 5. Auflage. - Tübingen ; Basel : A. Francke, 2007. - S. 190-191. 5. Ribeca C. E-learning im Fremdsprachenunterricht [Електронний pecypc]/ C. Ribeca. - Режим доступу: www.italienisch-online-lernen.de 6. Rösler D. Blended Learning im Fremdsprachenunterricht / D. Rösler, N. Würffel // Fremdprache Deutsch. - Heft 42. 2010. - S. 5-11.

УДК [378:02:002.1](73)

Світлана Чуканова

\section{ІНФОРМОЛОГІЯ ЯК СКЛАДНИК ДИСЦИПЛІНИ «БІБЛІОТЕКОЗНАВСТВО ТА ІНФОРМОЛОГІЯ» У ПРОЦЕСІ ПРОФЕСІЙНОЇ ПІДГОТОВКИ МАЙБУТНІХ ФАХІВЦІВ У ВНЗ США}

Чуканова С. О. Інформологія як складник дисципліни «Бібліотекознавство та інформологія» у процесі професійної підготовки майбутніх фахівців у ВНЗ США.

Статтю присвячено питанню значущості інформології як складника навчальної дисципліни «Бібліотекознавство та інформологія» у вищих навчальних закладах Сполучених Штатів Америки.

Ключові слова: вища бібліотечна освіта, Американська бібліотечна асоціація, інформологія, бібліотекознавство, освітні акредитаційні стандарти, теорія інформації, професійна підготовка майбутніх фахівців.

Чуканова С. А. Информология как составляющая дисциплины «Библиотековедение и информология» в процессе профессиональной подготовки будущих специалистов в вузах США.

Статья посвящена вопросам изучения сущности информологии в составе дисциплины «Библиотековедение и информология» в высших учебных заведениях Соединенных Штатов Америки.

Ключевые слова: высшее библиотечное образование, Американская библиотечная ассоциация, информология, библиотековедение, образовательные аккредитационные стандарты, теория информации, профессиональная подготовка будущих специалистов.

Chukanova S. O. The Information Science as a constituent part of Library and Information Science discipline during professional training at higher educational establishments in the USA.

The article is dedicated to the importance of Information Science as a part of Library 
and Information Science educational discipline in the USA.

Key words: higher education in LIS, American Library Association, Library and Information Science, educational accreditation standards, information theory, professional training of future specialists.

Процес акредитації магістерських програм із бібліотекознавства й інформології у ВНЗ США контролюється Американською бібліотечною асоціацією та здійснюється на основі вироблених нею стандартів. Варто зазначити, що задля отримання роботи за фахом ступінь магістра бібліотечних та інформаційних наук $є$ обов'язковим. Процес акредитації бібліотечних магістерських програм Американською бібліотечною асоціацією надає змогу випускникам цих програм отримати необхідний мінімальний рівень підготовки. Відповідно до вимог, зазначених у «Стандартах 3 акредитації магістерських програм 3 бібліотекознавства та інформології», розроблених Американською бібліотечною асоціацією, сучасний бібліотекар повинен володіти базовими знаннями в області інформології [11]. Нині професія бібліотекаря у США тісно пов'язана з інформаційною наукою, таку ж тенденцію констатуємо на теренах сучасної України.

Оскільки дисципліна «Інформологія» для України $\epsilon$ досить новою, а упровадження ii до бібліотечної освіти наразі тільки починає набирати обертів, актуальним залишається питання взаємозв'язку цих дисциплін на теренах України.

Meта статmi - розкрити взаємозв'язок інформології з бібліотечною справою як освітньою дисципліною у ВНЗ США.

Питанням вивчення інформології як дисципліни опікуються вітчизняні та зарубіжні науковці. 3-поміж українських дослідників, які переймаються загальними питаннями інформології й кібернетики можемо назвати: В. Камша, Л. Камша, Ю. Камша та ін. [4]. Питання співвіднесення інформології з документознавством та бібліотекознавством досліджувались В. Горєвою, Л. Данильчук [1;2]. Зарубіжні науковці: Р. Блаут, Б. Брукс, Дж. О’Салліван, Д. Снайдер, К. Шеннон досліджували основи інформаційної теорії та співвіднесення інформології з іншими науками $[5 ; 7 ; 10]$. Застосуванням інформології у бібліотечній справі на теренах США опікуються провідні бібліотекознавці цієї країни: К. МакКук, Дж. Олсгаард, Р. Рубін та ін. [6; 8; 9].

Власне інформології (загальній теорії інформації) покладено початок американським інженером, математиком Клодом Шенноном (1916-2001). У своїй статті від 1948 року «Математична теорія комунікації» він запропонував семантичну схему системи комунікації (рис. 1) (тут та надалі переклад з англійської мови наш С.Ч.) $[10$, с. 2]. Ця схема використовується не лише інформологами, бібліотекарями чи інженерами, але й широко застосовується у галузі перекладу загалом та в усному двосторонньому перекладі зокрема. Ми можемо використовувати схему, запропоновану К. Шенноном задля унаочнення процесу роботи 3 інформаційними ресурсами у бібліотеці, тобто прослідкувати передавання інформації від місця зберігання до кінцевого користувача посередництвом різних відділів бібліотеки. 


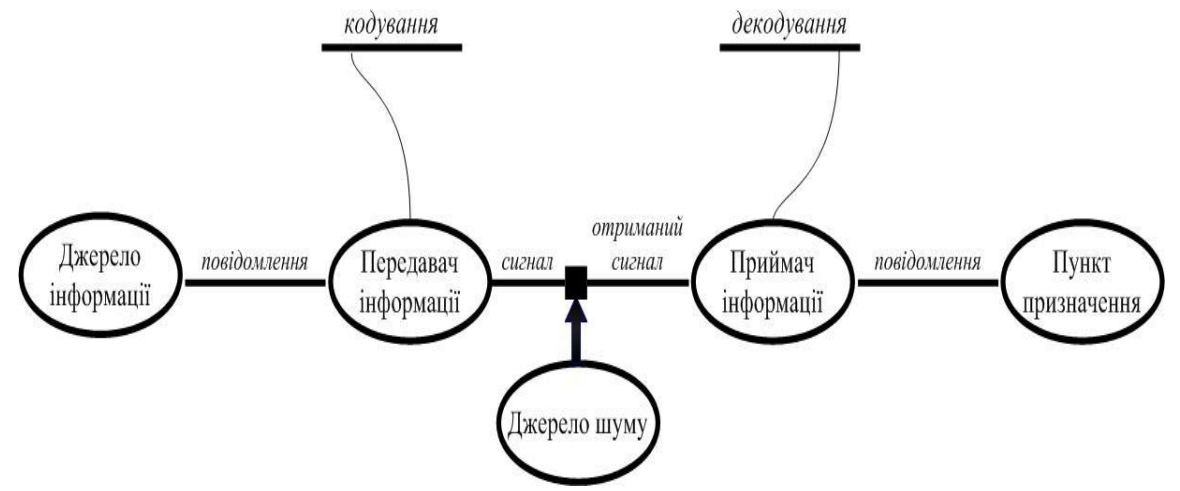

Рис. 1. Схема системи комунікації (К. Шенноном)

Цю схему можна пояснити так:

1. Джерело інформації продукує повідомлення для приймача.

2. Передавач опрацьовує повідомлення, перетворюючи його на сигнал (здійснює кодування).

3. Сигнал йде по каналу (засобу транслювання сигналу від передавача до пункту призначення).

4. Приймач декодує (розшифровує) отриманий сигнал.

5. Пункт призначення - реципієнт (особа або пристрій) отримує призначене повідомлення.

Як видно зі схеми, основною метою процесу є передача інформації від джерела до пункту призначення шляхом кодування інформації у сигнал із використанням передавача $\mathrm{i}$ декодування сигналу повідомлення із використанням приймача, враховуючи при цьому джерело шуму, що може певним чином уплинути на сприйняття отриманого повідомлення при декодуванні [10].

Ця схема була розширена та модернізована нашими сучасниками, науковими співробітниками Американського Інституту Інженерів-Електриків: Дж. О'Салліваном, Р. Блаутом та Д. Снайдером [7]. Принцип передавання інформації, на їхню думку, залишився такий самий, але розбитий на два етапи: формування образу й комунікативну модель (рис. 2).

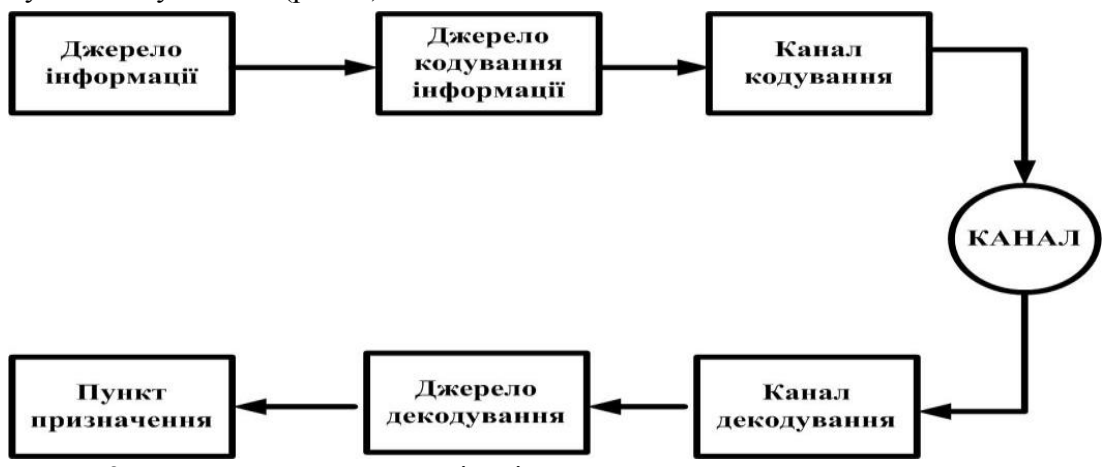

Рис. 2. Розширена схема комунікації 
У своїй статті, присвяченій інформологічним дослідженням, завідувач сектору нормативно-методичного забезпечення діловодства управління діловодства, формування i зберігання НАФ Державного комітету архівів України В. Горєва описує історію походження інформології як науки, зазначаючи, що у 1974 р. В. Сіфоров назвав науку про інформацію або інформологію «суттєво важливою ланкою сучасної науково-технічної революції», а також визначав інформологію як «науку про процеси і закони передавання, розподілення і перетворення інформації» [1, с. 47]. На його думку, ця наука займається вивченням таких процесів: «кодування, декодування, запам'ятовування, збереження пошуку, доставлення, порівняння, відображення, виробництва, перетворення, споживання інформації» [1, с. 47].

Функції інформології певною мірою суголосні функціям бібліотечної справи, яка покликана створювати, зберігати, управляти та розповсюджувати інформаційні ресурси та матеріали. Тому варто говорити про взаємний зв'язок цих дисциплін, адже вони обидві мають справу 3 інформацією у різних іiі виявленнях. Зв'язок теорії інформації до бібліотечної справи можна прослідкувати, проаналізувавши перелік обов'язкових дисциплін, які вивчають студенти магістерських програм із бібліотекознавства й інформології у ВНЗ США: аналіз, оцінка, синтез та розповсюдження матеріалів; документознавство та робота 3 інформаційними ресурсами; збереження та видача матеріалів; комплектування та каталогізація інформаційних ресурсів; консервація матеріалів; менеджмент ресурсів; основи комунікації; послуги та технології у галузі використання інформаційних матеріалів; створення інформаційних ресурсів. Як видно 3 поданого переліку створення та управління інформаційними ресурсами, а також основи комунікації $є$ важливими дисциплінами для бібліотечної освіти у США.

На думку сучасного американського бібліотекознавця Річарда Рубіна, основним завданням бібліотекаря є створення, упорядкування, збереження, розповсюдження інформації. Комунікаційна схема Клода Шеннона, покладена в основу роботи 3 інформаційними ресурсами у бібліотеці, на нашу думку, може мати такий вигляд (рис. 3):

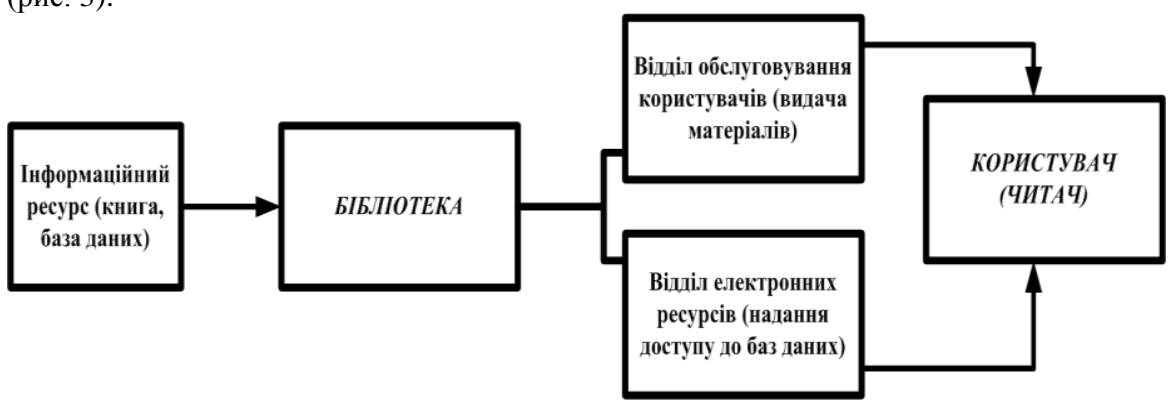

Рис. 3. Схема роботи з інформаційними ресурсами у бібліотеці

Оскільки інформація нині наявна у різних видах: як друкованому, так i електронному, то можемо говорити про двофазну модель передачі інформації в залежності від того, який ресурс був запитаний користувачем [3]. Зі схеми видно, що різні підрозділи бібліотеки можуть відповідати за різні напрямки роботи 3 джерелами інформації. Скажімо, 3 друкованим фондом працює відділ обслуговування, тоді як відділ електронних ресурсів працює з базами даних чи електронними джерелами.

Взаємозв'язок інформології та бібліотечної справи $\epsilon$ очевидним 3 огляду на 
причетність цих наук до інформації загалом та інформаційних ресурсів зокрема. Узявши за основу теорію інформації та базову комунікаційну схему, запропоновану Клодом Шенноном ще у 1948 році, можемо використати іï як матрицю для перенесення процесу роботи 3 інформацією у бібліотеці, де сигналом або повідомленням $є$ інформаційний ресурс, що передається бібліотекою через ії підрозділи до кінцевого споживача - читача. Сучасний бібліотекар у США повинен володіти базовими знаннями 3 інформології, оскільки сучасні бібліотеки оснащенні різними технічними пристроями, що суттєво оптимізують передавання інформації: комп'ютерами, планшетними комп'ютерами, електронними читанками (рідерами). Окрім того, більшість бібліотек мають автоматизовані процеси, працюють з інтегрованими бібліотечними системами, і знання 3 інформології $\epsilon$ необхідними для роботи у таких бібліотеках. Саме тому магістерські програми із бібліотекознавства та інформології у США та Канаді, що мають акредитацію від Американської бібліотечної асоціації, обов'язково вносять до навчального плану дисциплін інформаційного характеру.

\section{Література}

1. Горєва В. В. Інформологічні дослідження в документознавстві України у 60$70-\mathrm{x}$ роках XX ст. (на прикладі досліджень Української філії науково-дослідного інституту планування і нормативів при Держплані СРСР у м. Києві) / В. В. Горєва // Архіви України. - 2011. - № 2-3 (273). - С. 46-56. 2. Данильчук Л. Сутність дефініції «інформація» / Л. Данильчук // Педагогіка і психологія професійної освіти - 2012. № 5. - С. 18-26. 3. Електронні книжки та електронні читанки (рідери) в бібліотеці : 3 чого почати? / [уклад. : Пашкова В. С., Ярошенко Т. О. ; відп. за вип. Я. С. Сошинська]; Українська біб. асоц., Нац. парлам. б-ка України, Нау. б-ка Нац. ун-ту «КиєвоМогилянська академія». - К. : [Самміт-книга], 2013. - 63, [1] с. : іл. 4. Камша В. П. Про кібернетику другого етапу НТР / В. П. Камша, Л. С. Камша, Ю. В. Камша // Складні системи і процеси - 2010. - № 1. - С. 25-41. 6. Brookes В. С. The foundations of information science : Part I. Philosophical aspects. / B. C. Brookes // Journal of information science - 1980.№ 2. - P. 125-133.7. McCook K. Opportunities in Library \& Information Science Careers / McGraw-Hill, 2001. - 160 p. 8. O'Sullivan J. A. Information-theoretic image formation / J. A O'Sullivan, R. E Blahut, D. L. Snyder // IEEE Transactions on Information Theory - 1998 V. 44. - № 6. - P. 2094-2123. 9. Principles and applications of information science for library professionals / J. N. Olsgaard, editor. - Chicago : American Library Association, 1989. - 142 p. 10. Rubin R. E . Foundations of Library and Information Science / R.E. Rubin. - New York : Neal-Schuman Publishers, Inc. , 2004. - 495 p. 11. Shannon C. E. A mathematical theory of communication / C. E Shannon // ACM SIGMOBILE Mobile Computing and Communications Review - 2001. - № 5- P. 3-55. 12. Standards for Accreditation of Master's Programs in Library and Information Studies / [Електронний ресурс].- Режим доступу : http://www.ala.org/accreditedprograms/sites/ala.org.accreditedprograms/files/ content/ standards/ standards_2008. pdf. - Назва з екрана. 